\title{
Analysis of the Difference between INA-CBG Rates and Hospital Rates for Outpatient and Inpatient Services at FKRTL Provider BPJS Kesehatan Mataram City
}

\author{
*Putu Gede Wawan Swandayana, Sastrawan \\ Master of Health Administration Study Program, Faculty of Health, Universitas Qamarul \\ Huda Badaruddin Bagu, Jl. H. Badaruddin Bagu 83562, INDONESIA \\ *Corresponding Author e-mail: swandayana25@gmail.com
}

Received: September 2021; Revised: October 2021; Published: December 2021

\begin{abstract}
The National Health Insurance Program or Jaminan Kesehatan Nasional (JKN) managed by the Health Social Security Administration Agency or Badan Penyelenggara Jaminan Sosial Kesehatan (BPJS Kesehatan) has entered its eighth year of implementation. Since 2014, PT Askes (Persero) has transformed into BPJS Kesehatan, this also has an impact on changes in the payment system from Retrospective Payment System to Prospective Payment System with INA-CBG (Indonesian-Case Based Groups) rates. The difference between INA-CBG rates and hospital real rates is a fundamental problem, so hospitals must make efforts to achieve quality control and cost control. The real rate is the rate used by the hospital based on service of each service according to local regulations. Meanwhile, INA-CBG is a case-based health financing package by grouping various types of services into one unit. There is a difference between the INA-CBG rates and the hospital's real rates for paying JKN claims for Advanced Inpatient (RITL) and Advanced Outpatient (RJTL) services as a whole. This study is a descriptive-analytic quantitative research. The data used is secondary data obtained from the list of hospital JKN claims on the BPJS Kesehatan Claims Digital Verification application. The results of the study indicate that there is a negative difference between the total INA-CBG rate and the total hospital real rate for inpatient services of Rp. $-25,654,787,895$ or $-36 \%$ of the INA-CBG rate. In outpatient services there is a negative difference of Rp. $-6,144,370,328$,- or $-13 \%$ of the INA-CBG rate. Based on these findings, we recommend that hospitals should conduct a utilization review of health services, as well as calculate the appropriate unit cost for each type of service. The hospital carries out quality control of services by paying attention to the diagnosis and action and treatment provided, so that there are no unnecessary services.
\end{abstract}

Keywords: rates difference, health services, outpatient and inpatient.

How to Cite: Swandayana, P., \& Sastrawan, S. (2021). Analysis of the Difference between INA-CBG Rates and Hospital Rates for Outpatient and Inpatient Services at FKRTL Provider BPJS Kesehatan Mataram City. Prisma Sains : Jurnal Pengkajian Ilmu dan Pembelajaran Matematika dan IPA IKIP Mataram, 9(2), 246-252. doi:https://doi.org/10.33394/j-ps.v9i2.4350

\section{INTRODUCTION}

In the health financing system in hospitals, Indonesia developed the Casemix system in 2006 under the name INA-DRG (Indonesian-Diagnosis Related Group). Implementation of hospital payments with INA-DRG began on 1 September 2008 at 15 vertical hospitals. In September 2010 the nomenclature was changed from INA-DRG to INA-CBG (IndonesianCase Based Group) in line with the change in grouper from 3M Grouper to UNU (United Nation University) Grouper (Wibowo, 2014). Indonesia Case Based Groups (INA-CBG) rates for hospitals are applied according to the Minister of Health Regulation No. 52 of 2016 concerning Standard Rates for Health Services in the Implementation of the Health Insurance Program (Kementerian Kesehatan Republik Indonesia, 2016). 
Indonesian-Case Based Group (INA-CBG) rate is the amount of claim payment by BPJS Kesehatan to Advanced Level Referral Health Facilities or Fasilitas Kesehatan Rujukan Tingkat Lanjutan (FKRTL) for service packages based on disease diagnosis groupings and procedures. There are a number of aspects that affect the cost of INA-CBG, namely the primary diagnosis, the presence of a secondary diagnosis in the form of comorbidities or complications, the severity, the form of intervention, and age of the patient.

The INA-CBG rate consists of outpatient and inpatient rates, which are grouped by class, specialty, and hospital ownership. The INA-CBG rate consists of five regional rates which are determined based on the Province in Indonesia. The province of West Nusa Tenggara is included in the two regional rates along with the provinces of West Sumatra, Riau, South Sumatra, Lampung, and Bali (Kementerian Kesehatan Republik Indonesia, 2016).

Presidential Regulation of the Republic of Indonesia Number 12 year 2013 concerning Health Insurance as amended by Presidential Regulation Number 111 year 2013, mandates that rates be reviewed at least every 2 (two) years. The INA-CBG rate has been issued in accordance with the Regulation of the Minister of Health Number 52 year 2016 as a formal legal ratification of improvements from the previous INA-CBG rate, namely Minister of Health Regulation Number 59 year 2014 concerning Health Service Rate Standards in the implementation of the Health Insurance Program. In addition, there is also the Minister of Health Regulation Number 76 year 2016 concerning INA-CBG Guidelines. However, until now there has been no change in the INA-CBG rate.

The development of hospital services with standardized financing or payments is expected to provide many benefits for patients, health service providers and funders. There has been a drastic development in health financing since the reform of health financing, namely the National Health Insurance or Jaminan Kesehatan Nasional (JKN) was implemented in 2014. There has been an extraordinary increase in the utilization of health facilities. The burden due to the increasing number of patients in several hospitals is a complaint of health workers. Several hospital management complained about the INA-CBG rate which was considered not to meet the adequacy of the real cost of service (actual cost).

The implementation of INA-CBG in the series of implementation of the JKN program still faces many obstacles, one of which is regarding the INA-CBG package, it turns out that some FKRTLs are below the real hospital rates. Based on data obtained from the hospital provider BPJS Kesehatan Cabang Mataram, there is a difference between the INA-CBG rate and the hospital's real rate based on the type of service. There are FKRTL where the INACBG rate is higher than the real hospital rate, for example the RSIA Permata Hati hospital where the INA-CBG rate is Rp. 2,105,597,800,- while the real rate for the hospital is Rp. $1,966,464,724$,- there is a positive difference of Rp. 139,133,076,- or 7\%. However, there are also INA-CBG rates which are lower than the real rates for hospitals such as the Universitas Mataram Hospital where the INA-CBG rate is Rp. 1,927,887,100,- while the real rate for the Hospital is Rp. 3,745,357,510, - there is a negative difference of Rp. $(1,817,470,410,-)$ or $49 \%$. Based on the foregoing, the researcher wants to study further about the difference between real hospital rates and INA-CBG rates at the FKRTL Provider BPJS Kesehatan Cabang Mataram.

\section{METHOD}

This study is a descriptive-analytic quantitative research. A quantitative approach is used to compare the real hospital costs that should be paid by the patient with the costs borne by BPJS Kesehatan based on the INA-CBG rate. The research was conducted from January to May 2021.

The data used in this study is secondary data obtained from the list of filing claims for JKN Hospitals on the application of Digital Verification Claims of BPJS Kesehatan. The research instrument used is a digital form from the BPJS Kesehatan claim application. The 
list of hospitals whose data is used as a comparison of INA-CBG rates with the real rates of hospitals in the city of Mataram is presented in Table 1.

Table 1. List of hospitals by class and ownership

\begin{tabular}{|c|c|c|c|}
\hline FKRTL name & Class & Ownership & $\%$ \\
\hline RS JIWA PROVINSI NTB & \multirow{3}{*}{ B } & \multirow{3}{*}{ Government hospital } & \multirow{3}{*}{$25 \%$} \\
\hline RSU PROVINSI NTB & & & \\
\hline RUMAH SAKIT UMUM KOTA MATARAM & & & \\
\hline RS MATA NUSA TENGGARA BARAT & \multirow{3}{*}{$\mathrm{C}$} & \multirow{3}{*}{ Government hospital } & \multirow{3}{*}{$25 \%$} \\
\hline RS UNIVERSITAS MATARAM & & & \\
\hline RUMKIT BHAYANGKARA TK. III MTR & & & \\
\hline RSIA PERMATA HATI & \multirow{3}{*}{$\mathrm{C}$} & \multirow{3}{*}{ Private hospital } & \multirow{3}{*}{$25 \%$} \\
\hline RUMAH SAKIT HARAPAN KELUARGA & & & \\
\hline RUMAH SAKIT ISLAM SITI HAJAR & & & \\
\hline RUMKIT Tk IV WIRA BHAKTI MATARAM & $\mathrm{D}$ & Government hospital & $8 \%$ \\
\hline KLINIK BERSALIN UTAMA AKASIA & \multirow{2}{*}{ D } & \multirow{2}{*}{ Private hospital } & \multirow{2}{*}{$17 \%$} \\
\hline RSK ST ANTONIUS & & & \\
\hline
\end{tabular}

The list of hospitals based on class and ownership (Table 1) shows as many as 12 hospitals providing BPJS Kesehatan Cabang Mataram consisting of; 3 of class B government hospitals $(25 \%), 3$ of class C government hospitals (25\%), 3 of class C private hospital (25\%), 1 of class D government hospital (8\%), and 2 of class D private hospitals (17\%).

Furthermore, based on the data in Table 1, the data analysis of the difference between the INA-CBG rates and the hospital's real rates for inpatient and outpatient services based on class and ownership, and treatment class was carried out. The difference in rates is described in nominal figures and as a percentage. This later became the findings in this study.

\section{RESULTS AND DISCUSSION}

The difference between the INA-CBG rates and the real rates for advanced inpatient services based on class and hospital ownership is presented in Table 2.

Table 2. The difference between the INA-CBG rates and the real rates for advanced inpatient services based on class and hospital ownership

\begin{tabular}{lrrrrr}
\hline \multirow{2}{*}{ Class and Ownership } & \multicolumn{2}{c}{ Rate (Rp.) } & \multirow{2}{*}{ Difference } & \multirow{2}{*}{ \% Difference } \\
\cline { 2 - 4 } & \multicolumn{1}{c}{ INA-CBG } & \multicolumn{1}{c}{ Real-Hospital } & & \\
\hline B Government hospital & 43.169 .674 .570 & 60.401 .799 .681 & -17.232 .125 .111 & $-40 \%$ \\
\hline C Government hospital & 5.857 .036 .200 & 9.400 .776 .291 & -3.543 .740 .091 & $-61 \%$ \\
\hline C Private hospital & 19.879 .727 .200 & 24.583 .316 .253 & -4.703 .589 .053 & $-24 \%$ \\
\hline D Government hospital & 1.818 .081 .100 & 1.892 .566 .300 & -74.485 .200 & $-4 \%$ \\
\hline D Private hospital & 261.243 .870 & 362.092 .310 & -100.848 .440 & $-39 \%$ \\
\hline TOTAL & $\mathbf{7 0 . 9 8 5 . 7 6 2 . 9 4 0}$ & $\mathbf{9 6 . 6 4 0 . 5 5 0 . 8 3 5}$ & $\mathbf{- 2 5 . 6 5 4 . 7 8 7 . 8 9 5}$ & $\mathbf{- 3 6 \%}$ \\
\hline
\end{tabular}

Based on the calculation results (Table 2), it is known that the total real hospital rate or costs incurred by the hospital for providing health services to patient JKN-inpatient is Rp. 96,640,550,835,-. Meanwhile, the total INA-CBG rate is Rp. 70,985,762,940,-. So that the overall difference for the months of service from January to May 2021 is Rp. $25,654,787,895,-$ or $-36 \%$ of the INA-CBG rate. The difference is negative because the total cost incurred by the hospital for providing health services to patient JKN-inpatients is greater than the total INA-CBG rate paid by BPJS Kesehatan. The highest negative difference is in class $\mathrm{C}$ of government hospital, which is $-61 \%$ of the INA-CBG rate. The lowest negative 
difference is found in class D government hospital, which is $-4 \%$ of the INA-CBG rate. There is no positive difference between the INA-CBG rate and the real hospital rate.

Table 3. Difference between INA-CBG rates and real hospital rates for advanced inpatient services based on class of care

\begin{tabular}{lrrrr}
\hline \multirow{2}{*}{ Class of Care } & \multicolumn{2}{c}{ Rate } & \multirow{2}{*}{ Difference } & \multirow{2}{*}{ \% Difference } \\
\cline { 2 - 3 } & INA-CBG & Real-Hospital & & -6.161 .799 .867 \\
\hline Class I & 19.388 .244 .580 & 25.550 .044 .447 & $-32 \%$ \\
\hline Class II & 16.398 .147 .190 & 20.388 .357 .100 & -3.990 .209 .910 & $-24 \%$ \\
\hline Class III & 35.199 .371 .170 & 50.702 .149 .288 & -15.502 .778 .118 & $-44 \%$ \\
\hline TOTAL & $\mathbf{7 0 . 9 8 5 . 7 6 2 . 9 4 0}$ & $\mathbf{9 6 . 6 4 0 . 5 5 0 . 8 3 5}$ & $\mathbf{- 2 5 . 6 5 4 . 7 8 7 . 8 9 5}$ & $\mathbf{- 3 6 \%}$ \\
\hline
\end{tabular}

Based on the results of these calculations (Table 3), it is known that the highest negative difference between the INA-CBG rate and the real hospital rate is in care class of 3, with a total INA-CBG rate of Rp. 35,199,371,170, - and the total real rate for the hospital is Rp. 50,702.149.288,-. So the amount of difference for the total cost of inpatient care for class 3 is Rp. $15,502,778,118$,- or $-44 \%$ of the INA-CBG rate. The lowest negative difference was in class 2 treatment at $-24 \%$ of the INA-CBG rate. There is no positive difference between INA-CBG rates and real hospital rates.

Table 4. The difference between the INA-CBG rates and the real rates for advanced outpatient services based on class and hospital ownership

\begin{tabular}{lrrrrr}
\hline \multirow{2}{*}{ Class and Ownership } & \multicolumn{2}{c}{ Rate } & \multirow{2}{*}{ Difference } & \multirow{2}{*}{ \% Difference } \\
\cline { 2 - 4 } & \multicolumn{1}{c}{ INA-CBG } & \multicolumn{1}{c}{ Real-Hospital } & & \\
\hline B Government hospital & 29.167 .317 .600 & 34.330 .664 .933 & -5.163 .347 .333 & $-18 \%$ \\
\hline C Government hospital & 6.679 .493 .400 & 7.214 .284 .009 & -534.790 .609 & $-8 \%$ \\
\hline C Private hospital & 10.592 .335 .300 & 11.183 .135 .254 & -590.799 .954 & $-6 \%$ \\
\hline D Government hospital & 826.984 .900 & 661.046 .786 & 165.938 .114 & $20 \%$ \\
\hline D Private hospital & 237.837 .100 & 259.207 .646 & -21.370 .546 & $-9 \%$ \\
\hline TOTAL & $\mathbf{4 7 . 5 0 3 . 9 6 8 . 3 0 0}$ & $\mathbf{5 3 . 6 4 8 . 3 3 8 . 6 2 8}$ & $\mathbf{- 6 . 1 4 4 . 3 7 0 . 3 2 8}$ & $\mathbf{- 1 3 \%}$ \\
\hline
\end{tabular}

Based on the calculation results (Table 4), it is known that the total real hospital rate or costs incurred by the hospital for providing health services to patients $\mathrm{JKN}$-outpatient is Rp. $53,648,338,628,-$. Meanwhile, the total INA-CBG rate is Rp. 47,503,968,300,-. So that the overall difference for the months of service from January to May 2021 is Rp. 6,144,370,328,or $-13 \%$ of the INA-CBG rate. The difference is negative because the total cost incurred by the hospital for providing health services to JKN-outpatient is greater than the total INACBG rate paid by BPJS Kesehatan. The highest negative difference is found in class B government hospitals, which is $-18 \%$ of the INA-CBG rate. The lowest negative difference is found in private hospitals class $\mathrm{C}$, which is $-6 \%$ of the INA-CBG rate. There is a positive difference in outpatient services at class D government hospitals with a total INA-CBG rate of Rp. 826,984,900,- and the total real rate for the hospital is Rp. 661,046,786,-. So the mount difference is Rp. 165,938,114, - or 20\%. The difference is positive because the total cost incurred by the hospital for providing health services to patients JKN-outpatient is smaller than the total INA-CBG rate paid by BPJS Kesehatan.

In the difference between the INA-CBG rate and the real rate at the hospital, the real rate is calculated per details of the type of service, in this case the standard rate has been determined based on the regulation of the Mayor of Mataram Number 17 of 2014 concerning Service Rates for Hospitals. Where the cost of health services is calculated on a real basis by taking into account the socio-economic capacity of the community and other local hospital rates as well as government policies. The rate for health services at hospitals in the city of 
Mataram includes components of facilities, services, and medical services according to the needs of each service. Meanwhile, the INA-CBG rate is a package rate that includes all components of hospital resources used in both medical and non-medical services. INA-CBG rate calculation is calculated based on the accumulation or merging of diagnostic codes and procedure/action codes into an INA-CBG code whose rate standards have been set by the government (Depkes, 2014).

The INA-CBG rates are also differentiated based on class and hospital ownership, where class A hospitals have higher INA-CBG rates compared to class B, C, and D hospitals for each class of disease diagnosis and medical treatment performed. Hospital ownership is divided between INA-CBG rates for government hospitals and private hospitals, but the amount of INA-CBG rates varies between government hospitals and private hospitals based on the grouper of disease diagnoses and medical actions taken.

Based on the analysis results, information is obtained that there is a significant difference between the INA-CBG rate and the real hospital rate. Statistically, the difference in the average (mean) rate of inpatient INA-CBG is Rp. 14,197,152,588, - with a mean real rate of inpatient hospital Rp. 19.328.110.167,-. Meanwhile, for outpatient services the average (mean) INA-CBG rate is Rp. 9,500,793,660, - with a mean real hospital rate of Rp. $10,729,667,725,-$.

If evaluated from inpatient services based on class of care according to Table 3 , most of the services are in class 3. The total INA-CBG rate for class 3 is Rp. 35,199,371,170,- or 50\% of the total INA-CBG rate. While the real rate for the hospital is Rp. 50,702,149,288,- or 52\% of the total real rate of the hospital. This indicates that more than $50 \%$ of services at the hospital are used for class 3 inpatient services. These differences can be influenced by several factors. According to Thabrani (2011), the factors that influence health costs are the inflation component of hospital costs, government policies, third party payers (insurance), and health workers themselves. Determination of service rates in hospitals both inpatient and outpatient based on the diagnostic classification in the INA-CBG. The diagnoses written in the medical resume and nursing records must be detailed and clear so as to make it easier to set the ICD 10 and ICD 9 CM codes in the claim application to be submitted to BPJS Kesehatan. The provider's ability and understanding of diagnostics using ICD-10 and ICD-9 CM which are the references in setting rates needs to be possessed (Lilissuriani, Saputra, \& Ruby, 2017). Not all of the diagnoses written in the medical record documents and patient nursing records can be included in the INA-CBG grouper because there are provisions related to coding rules in the claim data submission process. The amount of the claim depends on the INA-CBG grouper system which if the secondary diagnosis code entered is considered not a aggravating factor or affecting the main diagnosis, the grouper system will reject the secondary diagnosis (Kementrian Kesehatan RI, 2016).

Furthermore, the difference in costs is probably due to the fact that the hospital has not yet implemented Clinical Pathways (CP) in providing inpatient services so that it has an impact on procedures in patient care and treatment. The implementation of $\mathrm{CP}$ is closely related and related to Clinical Governance in order to maintain and improve the quality of services at an estimated and affordable cost (Dumaris, 2015). Quality control and cost control can be applied if the $\mathrm{CP}$ has been determined in accordance with applicable regulations. Medical service standards are not necessarily the same as Clinical Pathways which can be used as a component of cost analysis. Clinical Pathway is not used for estimating rates but for maintenance cost weight (directly related to the standardization of Length of Stay). The application of clinical pathways in the provision of inpatient services will greatly assist in establishing a diagnosis because the objectives of the Clinical Pathway include reducing service variations so that costs are more predictable, services are more standardized, improving the quality of care, improving costing procedures, improving the quality of the information that has been collected and as a counter-check especially in cases of high cost and high volume (Salim, 2020). 
The errors in providing diagnostic codes, both primary diagnoses and secondary diagnoses/complications by coding officers (coders) will also affect the results of the INACBG claim value. The accuracy of the determination of the diagnosis will have an impact on the accuracy of the determination of the INA-CBG rate group. Another possibility is the government's preparation of a rate list for the INA-CBG package, which is not yet balanced with the reality of the cost of hospital care. The diagnoses written on the medical record document and the patient's nursing record are also not included in the grouper because not all other diagnoses that arise are included in the main diagnosis so that the grouper does not consider it a diagnosis of complications.

\section{CONCLUSION}

From the results of research conducted on 12 FKRTLs in collaboration with BPJS Kesehatan in Mataram City regarding the difference between INA-CBG rates and real hospital rates for the months of service in January-May 2021. For inpatient services, the total real rate for the hospital is Rp. 96,640,550,835,- higher than the total INA-CBG rate of Rp. $70,985,762,940,-$. For outpatient services, the total real rate for the hospital is Rp. $53,648,338,628$,- higher than the total INA-CBG rate of Rp. 47,503,968,300. There is a negative difference of $-36 \%$ between the total INA-CBG rate and the total hospital real rate for inpatient services. Negative difference of $-13 \%$ between the total INA-CBG rate and the total hospital real rate for outpatient services. A positive difference of $20 \%$ between the total INA-CBG rate and the total real hospital rate for outpatient services at class D hospitals owned by the government. A negative difference of $-44 \%$ between the total INA-CBG rate and the total real hospital rate for inpatient services in class 3. Overall, the total INA-CBG rate is still under total real hospital rate with a total negative difference of $-27 \%$.

\section{RECOMMENDATION}

Based on the findings of this study, we recommend hospitals to conduct a utilization review of the health services provided to patients, as an effort to control quality and control costs. In addition, hospitals need to calculate the appropriate unit cost for each type of service and provide input to local governments regarding rational hospital rates. Hospitals need to provide training and coaching for coding staff (coders) related to coding rules and coding procedures in accordance with ICD 10 and ICD 9 CM. More generally, hospitals must improve the quality of services by making clinical pathways and Clinical Practice Guidelines for each type of service.

\section{ACKNOWLEDGMENT}

The authors would like to thank those who have collaborated and assisted in the process of this study.

\section{REFERENCES}

Depkes, RI. (2014). Peraturan Menteri Kesehatan Republik Indonesia Nomor 27 Tahun 2014 Tentang Petunjuk Teknis Sistem Indonesian Case Base Groups (INA-CBGs). 50.

Dumaris, H.(2015). Analisis Perbedaan Tarif Rumah Sakit Dan Tarif INA-CBG ' s Pelayanan Rawat Jalan Di RSUD Budhi Asih Jakarta Tahun 2015. Jurnal Administrasi Rumah Sakit 3(1), 20-28.

Handayani, L., Suharmiati., \& Niniek L., P. (2019). Unit Cost Rumah Sakit Dan Tarif InaCbgs, Buletin Penelitian Sistem Kesehatan 21(4), 21-27.

Kementerian Kesehatan Republik Indonesia. (2016). Indonesian Case Based Groups (INACBG's) Dan Non Indonesian Case Based. Peraturan Menteri Kesehatan Republik Indonesia Nomor 52 Tahun 2016 Tentang Standar Tarif Pelayanan Kesehatan Dalam Penyelenggaraan Program Jaminan Kesehatan.

Kementrian Kesehatan RI. (2016). Peraturan Menteri Kesehatan Republik Indonesia Nomor 
76 Tahun 2016 Tentang Pedoman Indonesian Case Base Group (INA-CBG). 2016.” (92): 1-63. http://perhati-kl.or.id/wp-content/uploads/2017/08/PMK-No-76-2016.pdf.

Budiarto, W., \& Sugiharto, M. (2013). Biaya Klaim Ina Cbgs Dan Biaya Riil Penyakit Katastropik Rawat Inap Peserta Jamkesmas Di Rumah Sakit Studi Di 10 Rumah Sakit Milik Kementerian Kesehatan Januari-Maret 2012. Buletin Penelitian Sistem Kesehatan, 16(1 Jan). doi:10.22435/bpsk.v16i1 Jan.3146.

Lilissuriani., Saputra, I., \& Ruby, M. (2017). Perbedaan Biaya Riil Rumah Sakit Dan Rarif

INA-CBG Untuk Kasus Katastropik Dengan Penyakit Jantung Koroner Pada Pasien Rawat Inap Peserta Jaminan Kesehatan Nasional Di RSUZA. Jurnal Kesehatan Masyarakat 3(1): 198-205.

Munawaroh, S, Sulistiadi, W., \& Rachmad. (2019). Perbedaan Tarif INA-CBG's Dengan Tarif Riil Rumah Sakit Pada Pasien BPJS Kasus Stroke Iskemik Rawat Inap Kelas I Di RS PON Tahun 2018. Jurnal Manajemen Dan Administrasi Rumah Sakit Indonesia (MARSI) 3(2): 155-65. http://ejournal.urindo.ac.id/index.php/MARSI/article/view/532.

Salim, D., L., F. (2020). Aksesibilitas Pembiayaan Kesehatan Dalam Program Jaminan Kesehatan Nasional. Lex Et Societatis 8(4): 104-14.

Fadlilah, S., Sucipto, A., Rahil, N. H., \& Sumarni, S. (2020). Daun Sirsak (Annona Muricata L.) Efektif Menurunkan Kadar Gula Darah. Media Kesehatan Masyarakat Indonesia, 16(1), 15-25. Retrieved from https://journal.unhas.ac.id/index.php/mkmi/article/view/8864.

Wibowo, B. (2014). Tarif Ina - CBG Untuk JKN 2014. Case Mix Indonesia (27): 41 